\title{
Article \\ The Rise of Sustainable Consumerism: Evidence from the Egyptian Generation Z
}

\author{
Salma Khalil ${ }^{1}$, Ayman Ismail ${ }^{2}$ and Seham Ghalwash ${ }^{2, *(D)}$ \\ 1 Ottoman Group, Royal Herbs S.A.E, Shabramant, Giza 12947, Egypt; salmakhali1@aucegypt.edu \\ 2 Department of Management, School of Business, The American University in Cairo, New Cairo 11835, Egypt; \\ aymanism@aucegypt.edu \\ * Correspondence: sghalwash@aucegypt.edu
}

Citation: Khalil, S.; Ismail, A.; Ghalwash, S. The Rise of Sustainable Consumerism: Evidence from the Egyptian Generation Z. Sustainability 2021, 13, 13804. https://doi.org/ $10.3390 /$ su132413804

Academic Editor: Flavio Boccia

Received: 23 September 2021

Accepted: 11 November 2021

Published: 14 December 2021

Publisher's Note: MDPI stays neutral with regard to jurisdictional claims in published maps and institutional affiliations.

Copyright: (c) 2021 by the authors. Licensee MDPI, Basel, Switzerland. This article is an open access article distributed under the terms and conditions of the Creative Commons Attribution (CC BY) license (https:// creativecommons.org/licenses/by/ $4.0 /)$.

\begin{abstract}
Sustainable consumerism is a topic that is still being explored and developed across nations and countries. A new generation of consumers and the world's future leaders-Generation Z-have already begun to change the marketing and consumer landscape and have accelerated the means to achieve sustainable development. Meanwhile, the Egyptian Generation Z remains unexplored and ambiguous. The purpose of this article is to gain an understanding of the behavioral aspects of the Egyptian Generation Z, their consumerism, ecological consciousness, and corporate expectations. This exploratory research adopted qualitative methods using in-depth semi-structured interviews with a selected sample of participants representing the Egyptian Generation Z. The findings reveal an infantile but informed and reactive market of consumers whose acts of marketing and branding decisions contribute to reaching corporate sustainability, despite the fact they are viewed as nescient in the broader global community. This research provides the first evidence on the Egyptian Generation $\mathrm{Z}$ and their behavior towards sustainable consumerism in a new context of developing countries.
\end{abstract}

Keywords: sustainable consumerism; corporate sustainability; Generation Z; sustainability; developing countries; Egypt

\section{Introduction}

Sustainability has become one of the most important topics of our modern era due to the environmental challenges and nature degradation that the world is experiencing, which also impact people's habitats and quality of life [1-3]. These changes have induced sustainable consumerism movements among the world's youngest generation, the so-called Generation Z [4-6]. Basically, GenZers are classified based on common characteristics developed mainly by the emergence of technology and digital platforms, in addition to economic and environmental fluctuations [7]. Sustainability - as defined by the United Nations World Commission on Environment and Development-means meeting the resource needs of the current generations while preserving them for the coming generations [8]. Conceptually, sustainability is achievable through the integration of its three typical pillars: economic, social, and environmental, in any strategic framework or action plan [9]. The integration of the three pillars balances the whole process to achieve economic viability with social fairness and the least possible negative impact on the environment.

Likewise, corporate sustainability and the private sector's ecological compliance have attracted the world's focus $[8,9]$. The impact of their production processes and supply chains on people and the environment has imposed mandatory actions in an attempt to save the planet's ecosystem $[8,10]$. This movement has generated a new generation of products called green products $[11,12]$. To elaborate further, green products or eco-friendly products are described to be sustainably manufactured goods, or products promoting sustainable life, with minimal impact on the environment and resources [13]. These products have drawn the attention of the young generations, especially in the developed world, as a means to consume sustainably and put pressure on the private sector to become more 
responsible [6]. Consequently, third-party organizations, as well as producers of green products, have come into action to standardize and certify operational processes through eco-labeling their merchandise. In turn, multiple eco-labels have emerged in the market, creating diversity in the sustainability standards and their corresponding stamps such as Fairtrade and Rainforest Alliance stamps [14,15].

Corporate sustainability is one of the challenges faced by businesses while implementing the corresponding sustainability strategies and putting them into action [16]. Balancing the business financially is a hurdle due to the hardship of developing the economic sustainability pillar. Typically, sustainability work is directly linked to social and environmental development as a translation of the firm's philanthropic values [17]. Eventually, companies tend to perceive development as a charity act that boosts the company's reputation and positioning in the eyes of their customers and surrounding communities, which is typically referred to as "corporate social responsibility" (CSR) [7]. If there is an important element that businesses utilize to influence all their stakeholders, it is CSR, which impacts clients, shareholders, proprietors, investors, collaborators, and communities.

Numerous studies have focused on customer behavior toward eco-friendly and green products in developed countries [18-20]. However, a very limited number of studies have focused on the young generation and their behavior towards sustainable consumption in developing countries [13], especially Egypt. In fact, customers have become more conscious about the environment and green products in developing countries as well as developed countries [21]. Consequently, this study focused on the future generation of consumers which will, eventually, be leading the world in terms of governance, operation, demand, and supply in the context of the developing country of Egypt. Despite the controversies in Generation Z's age definition, they can be described as the population born after 1990 [22]. Members of Generation Z are global citizens born in the revolutionary age of technology which unites them to share common characteristics across countries. GenZers are tech-savvy individuals, digital media consumers, aware citizens, accustomed to having knowledge and information at their fingertips, and have their own set of values and expectations within their communities and ecosystem [23].

The means of achieving corporate sustainability through responsible consumerism is a significant topic to be explored, and there is a clear gap identified in the literature about GenZers and their consumerism [24]. Therefore, this research serves as an exploratory study of the Egyptian Generation $Z$ to understand their level of awareness about sustainability, their perspective of sustainable products, and how much they are willing to pay for them. Additionally, their expectations of FMCG companies in terms of values, environmental compliance, and social responsibility are also explored. Furthermore, this study assesses Egyptian GenZers' perception of the different sustainability labels such as the Fairtrade and Rainforest Alliance labels.

This exploratory qualitative research provides a guideline to understand the Egyptian Generation $\mathrm{Z}$ with their needs and expectations as well as the structure of the Egyptian market and the way it is evolving. Without a proper understanding of this generation, organizations will face difficulties in hiring future leaders who are required to achieve the Sustainable Development Goals. Thus, this study helps private sector corporates peek into their future and develop their social and environmental responsibility platforms according to their future customers' expectations. This study adopted in-depth interviews with the Egyptian Generation $Z$ to answer the research question: does the ecological awareness of the Egyptian Generation Z reflect on their consumerism, echoing a change in the Egyptian market and corporate approach to customer retainment? Therefore, the objective of this study was to understand the level of sustainability consciousness of the young generation in Egypt, their consumerism, and their impression of green products.

This article is structured as follows: First, the theoretical background reviews Generation $\mathrm{Z}$ and sustainable consumerism, followed by a presentation of the sustainable consumerism behavior constructs of Awareness, Motivation, Action, and Advocacy. Then, the research method is presented including the sampling, data collection, and analysis 
approaches adopted in this study. After that, the empirical findings of this research are presented and discussed in relation to the reviewed theory. Finally, this study concludes with the conclusion, practical implications, and limitations and future research.

\section{Literature Review}

\subsection{Generation $Z$}

Humans are the biggest influence on the whole ecosystem due to their needs, activities, development, and evolution. Accordingly, they define the world's economic pattern and the planet's quality of life. The newest population of human beings is called "Generation Z". They are also referred to as "Gen Z", "GenZers", and "Zoomers". GenZers are the successors of Millennials and the predecessors of Generation Alpha [25]. Primarily, it is useful to take a closer look at the various generations and study their differences and progressions. There is no doubt that the birth year, as well as political, economic, and cultural events, shapes the generations' identities and behaviors. As shown in Table 1, the behavioral traits of each generation are strongly connected to the surrounding atmosphere and ongoing historical events. Be it a global pandemic, a recession, or a state of war, they have all made a difference in shaping the world and its inhabitants, directly or indirectly.

Table 1. Comparative analysis of generations $[7,22,26]$.

\begin{tabular}{|c|c|c|c|}
\hline Generation & Birth Year Interval & Historical Events & Behavioral Traits \\
\hline Traditionalists & 1900-1945 & $\begin{array}{ll}- & \text { World War II } \\
- & \text { Start of Civil } \\
& \text { Rights } \\
& \text { Movements }\end{array}$ & $\begin{array}{ll}\text { - } & \text { Loyalty } \\
\text { - } & \text { Discipline } \\
\text { - } & \text { Value Authority } \\
\text { - } & \text { Conservative }\end{array}$ \\
\hline Baby Boomers & 1946-1964 & $\begin{array}{ll}\text { - } & \text { Post War } \\
\text { - } & \text { Dictatorship } \\
\text { - } & \text { Women's Rights }\end{array}$ & $\begin{array}{ll}\text { - } & \text { Responsibility } \\
\text { - } & \text { Idealistic } \\
\text { - } & \text { Collectivist } \\
\text { - } & \text { Workaholic }\end{array}$ \\
\hline Generation X & 1965-1980 & $\begin{array}{ll}\text { - } & \text { Capitalism } \\
\text { - } & \text { Democracy } \\
& \text { Domination } \\
\text { - } & \text { AIDS }\end{array}$ & $\begin{array}{ll}\text { - } & \text { Efficiency } \\
\text { - } & \text { Independent } \\
& \text { Thinkers } \\
\text { - } & \text { Materialistic } \\
\text { - } & \text { Competitive } \\
\text { - } & \text { Self-Reliance }\end{array}$ \\
\hline $\begin{array}{c}\text { Generation } \\
\text { Y/Millennials }\end{array}$ & 1981-1992 & $\begin{array}{ll}\text { - } & \text { Globalization } \\
\text { - } & \text { Prosperity } \\
\text { - } & \text { Technology and } \\
& \text { Internet } \\
& \text { Emergence } \\
\text { - } & \text { Terrorism } \\
\text { - } & \text { Swine Flu }\end{array}$ & $\begin{array}{ll}\text { - } & \text { Sociable } \\
\text { - } & \text { More Confident } \\
\text { - } & \text { Less Independent } \\
\text { - } & \text { Questioning } \\
\text { - } & \text { Higher Tolerance } \\
& \text { for Differences }\end{array}$ \\
\hline Generation Z & 1993-2012 & $\begin{array}{ll}\text { - } & \text { Digital Natives } \\
\text { - } & \text { Mobility } \\
\text { - } & \text { Social } \\
& \text { Networking }\end{array}$ & $\begin{array}{ll}\text { - } & \text { Poor } \\
& \text { Communication } \\
& \text { Skills } \\
\text { - } \quad \text { Extensive } \\
\text { - Technology Use } \\
\text { - Realistic }\end{array}$ \\
\hline
\end{tabular}

GenZers, or post-Millennials as some studies refer to them, are the youngest generation, accounting for 32\% of the global population in 2019 [6]. Generation Z is identified as individuals who were born in the mid-1990s; some studies mark the beginning of this generation as the year 1995, while others consider it 1997-1998, arguably ending between 2012 and 2018 [27]. Table 2 shows the different brackets of Gen $\mathrm{Z}$ in different types of studies. 
Table 2. Gen $\mathrm{Z}$ ranges in different studies [28].

\begin{tabular}{|l|l|}
\hline \multicolumn{1}{|c|}{ Age Range } & \multicolumn{1}{c|}{ Author(s) } \\
\hline Born 1990 or later & $\begin{array}{l}\text { Świerkosz-Hołysz (2016, p. 441); Żarczyńska-Dobiesz and } \\
\text { Chomaatowska (2014, p. 407); Wiktorowicz and Warwas (2016, } \\
\text { p. 22); Wojtaszczyk (2013) }\end{array}$ \\
\hline Between 1990 and 1999 & Half (2015) \\
\hline Between 1991 and 2000 & Tulgan (2009, p. 5) \\
\hline Between 1993 and 2012 & White (2017) \\
\hline Between 1993 and 2005 & Turner (2013, p. 18) \\
\hline After 1995 & $\begin{array}{l}\text { Opolska-Bielańska (2016, p. 37); Ensari (2017, p. 53); Dudek (2017, } \\
\text { p. 144) }\end{array}$ \\
\hline
\end{tabular}

However, it is agreed that this generation came with the rise of the World Wide Web, and many globally challenging circumstances and traumatic events. Members of Gen $\mathrm{Z}$ have experienced significant change in their lifetime thus far [29-31] - considerably higher than anything the world we know has ever experienced before-in addition to the unlimited potentialities and access they have to the global world, and the rise of multicultural and multi-racial countries [32]. Consequently, this generation has few similarities to their predecessors, the baby boomers and Millennials, and a lot of diversity within their age group's interests and demographics [33]. In contrast, other studies refer to Gen $\mathrm{Z}$ as the natural extension of Millennials due to the similarities they share in perceptions, beliefs, openness, environmental awareness, and sustainability concerns [4,6,33]. More importantly, the unprecedented technological hypes and advancement have made Gen $\mathrm{Z}$ the first digital natives functioning simultaneously between the virtual and real world with grace and ease, gaining content and information from the web yet contributing to its content as well [4]. Again, the only world they know allows them to attain any information instantly and build online social connections at the press of a button. Thus, they are independent in their knowledge, more than any other preceding generation $[6,32]$.

\subsection{Generation $Z$ Consumerism}

A focused glimpse of the sustainability and ecological consciousness of Gen Z indicates that they take after Millennials in their awareness and responsible consumerism [34,35]. Having their share of struggles with the global challenges resulting from the deterioration of the environmental and social conditions since the era of industrialization in the 1980s, Millennials took a leap in sustainable awareness and education that reflected on their behaviors in consumerism [35]. Gen Z, being raised in the 2000s, has taken after the Millennials given the fact that they also suffer from even more severe impacts on their ecosystem such as global warming and lack of resources [36,37]. Additionally, being constantly connected, stories about different corporate ecological behaviors roam around the world in no time. At that point, corporate citizenship, good or bad, is the real deal. To demonstrate, it has been reported by Elisabeth Best, Sustainability Manager at BSR (Business for Social Responsibility), that both Generations $\mathrm{Y}$ and $\mathrm{Z}$ are generating demand for ecological products [38]. Moreover, she mentioned that it has been revealed that $87 \%$ of Millennials versus $94 \%$ of GenZers believe that organizations are required to tackle social and environmental issues [38]. Thus, there is an undeniable rise in the tendency of the young generation towards sustainability and responsible consumerism. Consequently, closely studying Gen Z's consumerism behavior is mandatory for an adequate adaptation of the market and its stakeholders $[31,39,40]$.

\subsection{Sustainable Consumerism}

Sustainable consumption is fulfilling one's needs using good-quality products without compromising ecological health [41-43] —in other words, products with the least possible emissions of carbon dioxide or other pollutants, and the least toxicity, that are mostly natural, and with minimal impact on natural resources and the surrounding environment [40]. Green consumption is another term used to refer to sustainable consumption [44,45]. It im- 
plies the use of "green" products as a means of meeting our needs yet making eco-friendly choices. For example, a sustainable consumer would buy a low-energy light bulb, local food produce, organic fruits and vegetables with recyclable packaging, and many other examples of sustainable products [46]. A consumer with a sustainable mindset would tame and minimize their consumption to focus on the basic and important needs and fulfill them through high-quality ecological goods [47].

Another opinion suggests that sustainable living is adopting an anti-consumption approach rather than consuming responsibly [48-51]. With this intention, the consumer would use a perspective based on the three acts of rejection, reduction, and reuse [48]. First, it is believed that starting with rejection means refusing to consume in the first place, which would lead to minimal acts of buying and purchasing. Specifically, avoiding prints is a type of rejection, in addition to adopting an only organic buying behavior, which means that the consumer would not buy any food products unless they are organically cultivated and processed. The second act is reduction, which can be considered a form of anticonsumption. Reduction is a key pillar in any sustainable practice since it mostly lowers the consumption rate to a minimum [48,52]. Activities based on reduction can be adopted in our everyday activities, from reducing shower time for achieving water conservation, to carpooling as a means of reducing fuel usage and pollutant emissions [52,53]. It represents a form of releasing some of the pressure exerted on the different natural resources as well as the environment. The reducing approach omits consumption that is not based on real needs and eventually uplifts the efficiency of the individual's consumption patterns [48,54]. The third and last act of the anti-consumption approach is reusing. Reusing is a key element of sustainable behavior since it results in maximum use of a specific resource or element rather than dumping it and transforming it into waste [48]. For example, using reusable supermarket fabric bags instead of single-use plastic bags is an important form of reusing. Additionally, preserved foods' plastic and glass jars can be reused to store cooking staples and raw materials such as raw rice, seeds, and pasta. Thereupon, anti-consumption can be considered a stricter form of green and sustainable consumerism since it is based on a minimal, reliable, and efficient rate of consumption.

\subsection{Sustainable Consumerism and Customer Behavior}

While observing the behavior of sustainable consumers is important, it is equally significant to contemplate the reason behind their behavior $[55,56]$. As rational and logical as buying decisions seem to be, they are most likely to be driven by an emotional trigger [57]. Consumers with sustainable behaviors base their decisions when choosing environmentally friendly products on their values and ethics [58]. Shaefer and Crane explained that conscious individuals would spend effort, time, and money to promote their eagerness to restore nature and care for the ecosystem [11]. Understanding the behavior behind customers' sustainable choices is essential to promote sustainable consumerism. Our review of the literature identified four constructs that drive customers' sustainable consumption.

\subsubsection{Awareness}

Marketing is as vital as operations in being responsible and sustainable because raising consumers' awareness about ecological responsibility will increase their loyalty to green products and enhance responsible companies' equity and positioning [59]. Consequently, it is crucial to consider the limited resources that we have access to and raise awareness about sustainable consumption as well as green marketing [60-62]. In the era of digital connectivity, social media plays an important role in spreading awareness about sustainable consumption. Thus, it could be a tool to understand virtual communities and their sustainable consumption behavior [63]. Marketers have a great mediating role to communicate, raise awareness of, and encourage sustainable behavior, which was exemplified in 2018 by the NGO Globe Scan's sustainability survey results. The organization revealed that the first driver pushing companies to become more responsible is their reputation, followed by consumer demand [38]. Internationally recognized companies Toyota, General 
Electric, Walmart, and IKEA are examples of those that managed to create a competitive advantage through their CSR activities [64]. These firms succeeded in communicating their social and environmental activities to their consumers and the communities among which they exist [65]. As a result, they uplifted their positioning, increased their sales, established their sustainability platform, and situated themselves as good corporate citizens [64]. Eco-labeling is a marketing tool that can be used to promote the awareness of sustainable consumerism $[14,22]$.

\section{Eco-Labels}

Sustainable consumption of food and beverages is ensured through the application of many strategies such as eco-labels [66-68]. Sustainability labels are stamped logos on products such as coffee and chocolate, among other products, certifying them as sustainable. These eco-friendly labels serve as communication tools to the consumer for sustainability awareness, ensuring that consumers are aware that they can meet their needs without putting those of future generations at risk [67]. There exist several categories of fair trade which include, but are not limited to, Fairtrade, the Rainforest Alliance, carbon index schemes, and animal welfare [69]. These sustainability labels are further grouped into two groups, which are ethical eco-labels and environmental eco-labels. Of the four examples given, Fairtrade and animal welfare fall under ethical eco-labels, while on the other hand, the Rainforest Alliance and carbon index schemes fall under environmental eco-labels. This study leans more towards Fairtrade and the Rainforest Alliance; thus, it explores both ethical and environmental eco-labels [70,71].

When a consumer product is certified with a Fairtrade mark, it means that the producer has adhered to the Fairtrade specifications. The Fairtrade specifications are environmental, economic, and social specifications, which are core components of sustainable development. Fairtrade can similarly embrace corporate social responsibility and hence have a positive impact on society. The food industries can explore corporate social responsibility as they fulfill the agenda of giving back to the societies of both their employees and farmers [16].

Another eco-label is the Rainforest Alliance, which represents the environmental label category [70]. Any product stamped with a Rainforest Alliance Certification confirms that all the required specifications require environmental conservation, and employees' needs, and those of society, are met accordingly [72]. Some of the products that are associated with these certifications include, but are not limited to, furniture, flowers, toilet paper, tea, and coffee, such as Costa Coffee, the popular multinational coffee brand, with its Costa Coffee Rainforest Alliance Certification [73]. Since the Rainforest Alliance encourages growing crops under natural conditions, it promotes healthy products without the use of chemicals, which is recommended for sustainable health [74].

\subsubsection{Motivation}

The influence of the country context and surrounding environment on customers' choice to follow ethical consumption [75] and to buy organic products is ambiguous [45,76]. For example, individuals' motivation to buy sustainable products varies according to the country's wide aspect and the collective behavior, meaning individuals in developed and less developed countries might have different behavioral patterns [45]. Prior scholars identified several factors that motivate customers to buy sustainable and green products such as moral motivation that comes from deep inside the person's beliefs [75] and other external factors related to the country ecosystem [45]. Despite the similar level of consistency related to customers' drive to complete their purchases according to their sustainability aspects across several regions, the rates are lower in North America and Europe than in the Middle East, Africa, Asia, and Latin America [6]. In the emerging markets, consumers tend to have a more personal correlation with the communities that surround them, as they are much more aware of the daily issues and struggles, which makes them more prone to give back and spread goodwill. Regarding purchase decisions, studies have shown that convincing shoppers in developed countries to spend more money on sustainable products 
is challenging. On the other hand, $23 \%$ to $29 \%$ of shoppers in Latin America, Asia, the Middle East, and Africa have the will to spend more in exchange for green products [6].

\subsubsection{Action}

To understand consumers' behavioral action of buying sustainable products, Nielsen conducted a detailed survey based on thirty thousand consumers living in sixty different countries [6]. The survey took place between 2013 and 2015 on a variety of countries from Africa, Europe, the Middle East, Latin America, North America, and Asia-Pacific. The study measured the factors that may influence their buying decisions such as packaging, environmental concern, health and wellbeing, price, and marketing. The findings of the survey showed that consumers are eager to show their environmental responsibility through purchasing green products. For instance, the number of respondents who were willing to pay extra money for green products rose from 50\% in 2013 to 55\% in 2014 [77]. In addition to this, the findings included consumers from several backgrounds and different income levels ready to buy sustainable products even at higher prices, which reveals a common interest between multiple respondents. It is undeniable that Generation $Y$ has confronted various types of economic instabilities and challenges. Nevertheless, they portray a high level of awareness when it comes to environment conservation. This is reflected by their willingness to pay more for sustainable products. In $2014,50 \%$ of the respondents showed a willingness to pay for green products, and this percentage reached $73 \%$ in 2015. This rise in the percentage of purchasing approval constitutes a similarity with Generation Z, whose respondents showed a rise from 55\% in 2014 to $72 \%$ in 2015 [77].

The survey also signaled an important factor to be considered by brands offering sustainable products. This factor is the combination of the quality of the product and its effect on the health and wellbeing of consumers. Findings show that $57 \%$ of respondents invest in a product made from natural organic components that is proven to be healthy at the same time. In 2014, the brands who followed a marketing plan portraying their dedication to the values of their society and nature gained a higher percentage of product sales; a total of $43 \%$ of respondents showed interest in social values, and $41 \%$ manifested their interest in consumers' communities [6].

\subsubsection{Advocacy}

Sustainable consumption is vital, and individuals can collaborate with governments and corporates to tackle social and environmental issues. With the rapid increase in internet usage and social media, third sector organizations should focus their activities on advocacy virtual groups with the aim of reaching the public. By doing so, electronic advocacy groups can conduct possible actions to shape the understanding of sustainable consumption [78]. Thus, advocating the idea of consuming eco-friendly and sustainable products is crucial to move towards sustainability [6]. For example, in the US, Gen Z consumers' resolution to purchase sustainable food items can differ and having a marketing campaign that especially has environmentally aware Gen $Z$ buyers in mind is crucial to driving the purchasing power in the right direction. The reason behind this is that not all eco-conscious consumers-activists, believers, moderates, and advocates-put in the same effort when it comes to choosing sustainable food. The consumer behavior of activists recognized for environmental efforts has shown that they link their choice of food to healthy eating habits, such as choosing foods rich in nutrients and following a healthy diet, rather than other consumers who are not strict ecological advocates [12,53].

Given these points, marketeers would have an opportunity to generate consumer demand for eco-friendly and responsible products according to the growing sustainable consumption patterns. All things considered, the consumer plays the biggest and most important part in achieving sustainable consumption [79]. Their consistent demand for green and ecological products is the essence that drives businesses to meet this demand by adopting a more responsible mindset and integrating sustainability in their processes and products. The urge to supply the market with sustainable products is projected to 
increase as the population of both Generations $\mathrm{Y}$ and $\mathrm{Z}$ grows. This is due to their high influence as consumer and employee groups, in parallel with their high environmental awareness and concern [38]. With time and persistence, sustainable consumers could either drag companies into the eco-friendly zone or drive them out of business.

\section{The Research Context Importance}

Based on the previously discussed importance of Generation $Z$ and their significance as consumers and future leaders, the corresponding Egyptian Generation $Z$ was selected to conduct our study. The future Egyptian consumers and employees currently represent $52 \%$ of the population [80]. In other words, 52\% of Egyptians are under the age of 25 years old, with a gender distribution of roughly $51 \%$ males and $49 \%$ females [80]. These numbers emphasize the importance of more in-depth studies of this portion of the population which will shape the future of the Egyptian market and its consumers. To the best of our knowledge, there has been no research conducted on the Egyptian Generation $Z$ and sustainability issues. In order to fill this gap, this research provides the first evidence of the Egyptian Generation $Z$ and their behavior towards sustainable consumerism.

There is a scarcity of current studies related to the Egyptian Gen Z; however, it is believed that they would share various characteristics of the general global Gen $Z$ traits because of globalization and digital connectivity [7,22]. Research showed that the Egyptian young generation is highly influenced by the different social media platforms, depending on their corresponding interests, especially during the 2011 Egyptian revolution [81]. Accordingly, they show some awareness regarding sustainability keywords such as: "Plastic Waste", "Sea Pollution", and "Recycling". Nevertheless, they do not show a fair level of understanding of the general global sustainability challenges or those of Egypt. Additionally, the exploratory study showed that some individuals are working on transforming their lifestyle to a more sustainable one by using stainless-steel water bottles instead of mineral plastic bottles, installing water filters at home to avoid using water dispensers and their corresponding plastic water containers, replacing plastic cling film with beeswax covers or silicon adjustable covers, sticking to local produce and seasonable fruits and vegetables, reducing consumption of imported materials, carpooling, and many more eco-friendly initiatives. This behavior indicates that the future generation of Egyptian consumers will be leaning towards sustainable consumerism and will, eventually, catch up with the global Generation $\mathrm{Z}$ in terms of ecological responsibility.

\section{Methods}

\subsection{Research Design}

This study is an exploratory study aiming for a deep understanding of the Egyptian young generation's consumerism and the intensity of their ecological awareness. Exploratory research is useful when studying a new phenomenon that remains undefined, as suggested by Stebbins [82], which is the case of this study. This study adopted qualitative research methods due to their ability to comprehend trends, experiences, and diversity among one or more types of population [83]. With the qualitative approach, we can capture the participants' consumption experience and thus make sense of the perspectives they have of their world [84]. Initially, this qualitative study intended to answer the research question: does the ecological awareness of the Egyptian Generation $Z$ reflect on their consumerism, echoing a change in the Egyptian market and corporate approach to customer retainment? Qualitative research was the selected technique to run this investigation as an in-depth non-numerical method. Using qualitative methods is common for social studies in order to carry out experiments and gain insights and evidence to reveal the inner norms and structures of a specific society [85]. Moreover, the subject tackled by this study is considered a virgin topic, which is new and unexplored in the literature. Thus, it is important to study the behavior of the targeted sample in depth initially and therefore primarily resort to qualitative methods. 


\subsection{Sampling}

Qualitative research is an in-depth method of data collection and insight exploration [86]. Despite the flexibility of qualitative research methodologies, the sampling process remains one of the corresponding challenges. Since this research is focused on a specific tier of the upper socioeconomic class of the Egyptian Generation Z population, a mixture of convenience sampling and snowball sampling was used to select the research participants [86]. In particular, convenience sampling includes reaching out to accessible members of the researchers' surrounding community matching the study's sampling criteria [87]. More specifically, the snowball method is one form of convenience sampling entailing that the research participants help to recruit more subjects for the study from their acquaintances, respecting the targeted traits or characteristics [88]. Both methods were selected due to their convenience and accessibility to the researchers.

The sampling demographic criteria included both males and females from 21 to 29 years old. The upper bracket of the age group was borderline GenZers and Millennials, who were significant to the study due to their financial independence and ability to make their own purchase decisions. Geographically, the selected participants were inhabitants of Greater Cairo, since it represents the capital city and the country's biggest city with most of the targeted socioeconomic class. Equally important, the psychographic profile of the participants consisted of private college students such as the American University in Cairo, the German University in Cairo, and the British University in Egypt. Additionally, this study included young professionals working for multinational companies, or remarkable local businesses. This criterion was based on the literature's connotation stating that researchers opt for high socioeconomic tiers for sustainability studies in emerging markets and developing countries due to their high level of education, awareness, and prosperous lifestyle [87].

Fifteen GenZers, selected based on the previously mentioned criteria, were interviewed for this research. The semi-structured interviews were conducted during September and October 2020, and each interview lasted for an average time of 60 to 90 minutes. The sample size was determined according to the qualitative study concepts of diversity and data saturation [89]. Diversity was represented in the sample age (21 to 29 years old), educational background, marital status, and working experience as per Table 3 . On the other hand, data saturation in qualitative research is more subjective than in quantitative methods. Generally, data saturation is achieved whenever the research insights become repetitive and redundant [89].

Moreover, this study adopted the triangulation method to ensure the credibility and honesty of the data obtained from the informants [90]. This method suggests using data from different sources (i.e., a wide range of informants). Thus, four experts in the sustainability professional field-displayed in Table 3-were interviewed to obtain another perspective of the Egyptian market and, specifically, the consumerism of the Egyptian young generation. Two of the research experts worked in the field of sustainability consultancy and environmental assessment. The other experts were e-business owners selling green products in the Egyptian market online such as bamboo toothbrushes, stainless-steel straws, organic cotton baby garments, and wooden baby toys. 
Table 3. Participants' profiles.

\begin{tabular}{|c|c|c|c|c|}
\hline Gender & Code & Name & Age & Scope \\
\hline \multicolumn{5}{|c|}{ Expert Profiles } \\
\hline M & E01 & $\mathrm{AB}$ & & $\begin{array}{l}\text { Founder and CEO of a leading sustainability } \\
\text { consultancy firm }\end{array}$ \\
\hline $\mathrm{F}$ & E02 & MG & & $\begin{array}{l}\text { Communications Director of a leading } \\
\text { sustainability consultancy firm }\end{array}$ \\
\hline $\mathrm{F}$ & E03 & FS & & Sustainable baby garments \\
\hline $\mathrm{F}$ & E04 & $\mathrm{AA}$ & & Sustainable/green products \\
\hline \multicolumn{5}{|c|}{ Gen Z Participants } \\
\hline $\mathrm{M}$ & P01 & MA & 24 & Engineering student-GUC \\
\hline M & P02 & $\mathrm{OH}$ & 26 & Corporate employee-oil and gas sector \\
\hline $\mathrm{F}$ & P03 & RD & 26 & Married-corporate employee-FMCG \\
\hline $\mathrm{F}$ & P04 & RK & 29 & Full-time young mother \\
\hline M & P05 & $\mathrm{MH}$ & 21 & Architecture student-GUC \\
\hline $\mathrm{F}$ & P06 & FA & 25 & Senior editor-online fashion magazine \\
\hline $\mathrm{F}$ & P07 & SA & 25 & Financial consultancy services \\
\hline $\mathrm{F}$ & P08 & MH & 21 & Business student-AUC \\
\hline $\mathrm{M}$ & P09 & BS & 29 & Banker \\
\hline $\mathrm{M}$ & P10 & $\mathrm{OA}$ & 26 & Political science instructor-BUE \\
\hline $\mathrm{F}$ & P11 & MT & 21 & Business student-AUC \\
\hline $\mathrm{M}$ & P12 & MA & 27 & Engineer-corporate employee-oil and gas sector \\
\hline $\mathrm{F}$ & P13 & FS & 24 & \\
\hline $\mathrm{F}$ & P14 & DA & 24 & Start-up founder-retail sector \\
\hline $\mathrm{M}$ & P15 & OK & 27 & Family business-FMCG \\
\hline
\end{tabular}

Source: the authors.

\subsection{Data Collection}

In this study, the research process was run in the form of one-to-one online interviews using the Zoom or Face Time application, according to the participant's convenience. The COVID-19 pandemic made it difficult for us to conduct face-to-face interviews. Upon establishing a connection with the participants, they received a verbal brief from the researchers about the study objectives and types of questions as well as the consent form that guarantees their rights and privacy protection. Eventually, an appointment was set for the interview, as well as the application preference. The interview was in a semistructured format to allow the conversations to flow with the participants and extract the most possible insights [46]. A questionnaire was developed based on the four constructs of the sustainable customer behavior framework derived from the literature review and the previous studies of the Generation Z's consumerism in other countries. It served as a guiding tool through the conversation to cover different layers of the participants' personalities, beliefs, consumerism, and environmental concern and buying behavior. The interview questions were set to evolve around the participants' awareness about sustainability, and eco-friendly and green products; the motivations behind their decision to buy sustainable products; the factors that influence their purchasing actions; and their advocacy for sustainable consumption.

\subsection{Data Analysis}

Thematic network analysis was the methodology selected to analyze the research data. The thematic concept is to cluster the research findings in themes, and then find their interconnections, similarities, and contrasts [46]. Thus, this helps to develop a framework to organize the data findings and thread the results of the research neatly. The research results and findings were also compared with the literature to present an inclusive view of the information displayed.

\section{Results and Discussion}

The results and findings of the young Egyptian GenZers and their consumerism review are displayed in this section per the previously mentioned framework. The four layers of 
the framework are presented in detail as a contribution to studying and documenting the journey of Egyptian youngsters in terms of sustainability and responsible consumption. Their ideologies, contrasting thoughts, expectations, and values are supporting evidence of the research's hypotheses and findings.

Based on the information transcribed from the interviews and the thematic network analysis process, a concrete framework was developed to present the research findings. This framework, as shown in Figure 1, consists of four main consecutive categories: Awareness, Motivation, Action, and Advocacy. The framework is represented in a pyramid form since the number of contributors and interactors with each layer decreases as we dig deeper into the concept and ideology. This framework presents four layers of sustainable consumerism and green product awareness, where the Awareness category discusses the different ideologies in the consumers' minds and behaviors about sustainability, ecological challenges, responsible behavior, green products, and corresponding eco-labels. Motivation is the following category exhibiting the beliefs of the Egyptian GenZers, their environmental values, and their expectations from corporates and manufacturers in terms of sustainability. Next, the research explains the Actions taken by young consumers to become more responsible, their buying behavior, and their experience with sustainable products. Finally, this study sheds light on a thin yet potential layer of consumers: the Advocates. In this category, the motives, drives, and experiences of the young ecological advocates are demonstrated. Additionally, the social media influence and peer pressure contribution to this category are explored.

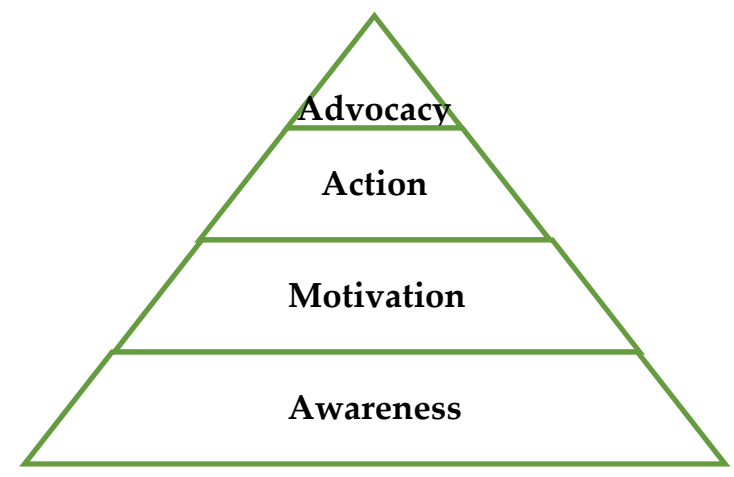

Figure 1. Sustainable consumerism framework. Source: the authors.

\subsection{Awareness}

According to the young generation's responses, there is a clear awareness of the true meaning of sustainability. More than half of the respondents described sustainability as continuity and permanence of natural resources. This definition matches the United Nations' definition of sustainability, mentioned in the literature review [91], with the only addition of including the generations to come. In other words, most of the participants showed high awareness of the ideology of consciousness and sustainability studies in the American University in Cairo, whereby sustainability is not only a concern of theirs but also a lifestyle and an integrated concept within their community culture.

"Going green is linked to plastic, big time. In other words, people perceive that sustainability means the elimination of plastic and that they do not understand the true meaning of sustainability." - SA, Female, 25 years old.

\subsubsection{The Awareness Level}

On the other hand, other respondents associated sustainability with green behavior, waste reduction, environment preservation, and recycling.

"I hear about Sustainability from my surrounding community lately, but I believe it is a trend or a hype. People don't understand the essence of sustainability, and others are claiming to be sustainable while they're not!"-BS, Male, 29 years old. 
While becoming popular recently, some people believe that sustainability is one of the trending waves that people use to become "cooler" or fancier. The concept is regarded as remarkable, and it indicates an uplifted profile of the adopting person. However, due to the lack of awareness within the Egyptian community and the absence of sustainability standardization and indicators, people tend to claim their consciousness despite their obvious contradicting behavior or lack of understanding. Nevertheless, when spotted in specific acts or behaviors, community members notice the behavioral pattern of becoming more responsible towards the environment and its resources.

"Sustainability acts are starting to be more popular around us, I even do some initiatives, and for example, I bought a tote Bag for groceries instead of plastic bags, when to my surprise the guy at the supermarket told me that a lot of people do the same because they do not want to use plastic." -FA, Female, 25 years old.

Likewise, despite the difference in the socioeconomic class (SEC), individuals with exposure to high SECs observe their responsible behavior and aspire to the foreseen elevated lifestyle. Accordingly, people with elevated educational backgrounds positively influence the behavior of others around them.

Although the level of alertness is increasing, as per the study responses, there are still gaps in acting towards responsible living. Awareness is moving at a slow growth pace since the concept is acquired through global advancement and international exposure through the internet and social media.

"People are becoming more aware, but only a minority is acting consciously. In Egypt, the sustainable movement is slowly growing." - RK, Female, 29 years old.

However, a real impact cannot be seen due to the absence of a national movement or structured curriculums leading to sustainable living. In particular, Dr. Abdelhamid Beshara, founder and CEO of the Masader firm that provides sustainability consultancy services, explained that the new generation in their twenties shows better understanding and performance in ecological consciousness and concern because of their extensive exposure to social media, movies, influencers, and modern educational curriculums in private schools and colleges.

"It is a global trend, and our young generation are becoming global citizens with their technology savviness and exposure to the whole world through their phones and gadgets."Dr. Beshara.

In line with Dr. Beshara's words, GenZers of Egypt expressed that their main sources of information about sustainability and consciousness are social media platforms such as Instagram, YouTube, Twitter, and Facebook [63,92]. They showed a high interest in learning more about responsibility and conscious behavior through online digital media channels. Moreover, most of them affirmed their willingness to follow credible platforms providing them with beneficial sustainability content, if they cross any. However, some of them mentioned that they prefer short video content, infographics, and a concise presentation of the provided data. These findings resonate with the literature describing the influence of technology and social media platforms on Gen Z and their characteristics $[7,11,24,26]$, and also their impatience and high expectations [22,33]. Moreover, some of them rely on information provided in their academic curriculums, and others on the knowledge they acquire from their jobs. Social media exposure allows users to wander the world and expand their knowledge through their handheld screens. Consequently, the young population perceive world problems, challenges, and experiences as theirs. In this sense, it was important to explore the alertness of the GenZers towards their own country's sustainability problems.

\subsubsection{Sustainability and Ecological Awareness Challenges}

Four main Egyptian sustainability challenges dominated the responses of the study participants: lack of awareness, water scarcity, waste management, and poor education 
systems. However, the lack of awareness was the common factor in almost all of the feedback.

"We have a huge problem due to lack of awareness and consumer mindset. For example, we reside in one of the top-class compounds on the Egyptian North Coast, yet people leave the beach showers open with no regrets about the running water they are leaving behind!"-RD, Female, 26 years old.

One participant explained her frustration towards people's carelessness, despite their high educational background and prosperous lifestyle. This segment of society is most probably aware of the importance of water as a natural resource; however, they lack concern and consciousness about the surrounding environment.

In contrast, other groups were concerned about the water problem in Egypt, due to their exposure to the national news and, more specifically, the Egyptian-Ethiopian debate about the latter's dam. Egypt is concerned about its share of the Nile water, which is foreseen to be negatively impacted by the construction of the Ethiopian dam. While Ethiopia aims for electricity, Egypt seeks water security, and the conflict is ongoing.

"The Water problem is in my concern because I see it, I've seen the Nile changing and its water level lowering, I am following the political conflict of Egypt and Ethiopia, and all the talk made me realize that we have a major water problem." - RK, Female, 29 years old.

Furthermore, respondents acknowledged the importance of governmental regulations and systems to promote Egypt's sustainability platform and mitigate the country's challenges. Additionally, interviewees stated that the country's regulations exist somewhere; however, there is no reinforcement or follow-up of their execution. At this point, it was essential to define responsibility and accountability for the young generation. It was agreed that the country requires awareness and education, as well as rules and regulations to control people's behavior and adjust it. Nevertheless, there are multiple stakeholders sharing responsibility and accountability. A group of respondents agreed that only the government is to be held responsible and accountable for this change and the country's development.

"The Government should be responsible to solve our ecological issues through raising awareness and educating people. I am 22 and I have not learned any of the sustainability topics at school. Also, most importantly they [the authorities] should be implementing laws and regulations."-MH, Male, 22 years old.

Another group mentioned that they believe in a collective effort, and that change needs to be driven from within the society, including the private sector and citizens, together with the authorities. Additionally, some views perceived the government as the project manager who needs all other stakeholders to attain success; however, the government drives the project and is held accountable for its success or failure. Meanwhile, others considered it an equally shared responsibility between the government, private sector, and consumers.

"First of all, the government; must develop policies, laws, and regulations and enforce their application. Also, they need to provide incentives and set penalties for different forms of violations. Secondly, in the private sector, they should put some focus on radical societal problems and invest in development. I mean generally, we would need collective efforts; however, the government should lead the change"-OH, Male, 26 years old.

Then, in terms of businesses and corporate citizenship in Egypt, experts' reviews were studied as a peek into the Egyptian corporate scene. Dr. Beshara explained that sustainability reporting, the most popular act of sustainability for the companies operating in Egypt, is just a process. However, $\mathrm{CO}_{2}$ reports are the ones that suggest a real commitment since companies are forced to reduce their footprint, and therefore they integrate the reduction in water, electricity, energy, waste, and packaging into their processes. Nevertheless, sustainability reporting is a much more common practice than $\mathrm{CO}_{2}$ reporting, which entails the superficiality of the corporates and their aim for propaganda. He added that big corporations in Egypt focus on marketing and communication, social 
development, and CSR platforms. They do not hire sustainability experts, and therefore there is no technical expertise to radically solve their problems. Additionally, they also introduce a lot of positive projects, but with no real impact on community challenges. In contrast, other experts indicated that there is a small segment possessing an adequate level of awareness. This segment is represented by a group of exporters working with international companies as clients, who impose criteria to meet sustainability compliance. Here, compliance provides them with the benefit of economic rewards by selling their products in international markets.

Another expert participant in the study stated that the people of Egypt are starting to become aware. From this participant's experience, namely, the bamboo toothbrushes and stainless-steel straws business owner, revealed that the first few days after she launched her online business were overwhelming. Customers flooded the business with orders, and it struggled to keep up with the ordering momentum. However, later, the clientele behavior changed from being driven by the sustainability ideology to being driven by social pressure and the global trend.

"First few days, I was overwhelmed by the number of placed orders. And then sales slowed down and instead of being based on awareness, it was more of based on trend and "coolness."-AA, Green Products Business Owner.

\subsubsection{Branding and Eco-Labeling-Awareness}

While some consumers lacked awareness about the Egyptian ecological challenges, they still showed concern towards the environment and biodiversity, even though, in some cases, they are inapplicable to the Egyptian ecosystem.

"When people order stainless straws, especially young customers, they often say "I want to save the turtles," which is considerate and conscious, but driven by global sustainability trends, indicating unawareness of our local challenges." $-A A$, continued.

As previously mentioned, green products are one of the pillars leading to corporate sustainability and environmental compliance. Making conscious buying decisions promotes sustainable consumption and therefore supports ecological viability. The young generation showed familiarity with the concept of green products; however, some of them were confused regarding green product classification and standardization.

"Green products can be described as anything that helps the environment from the sustainability perspective such as renewable energy, $P V$ panels, and so on." $-R D$, Female, 26 years old.

While most participants stated that there is a clear shortage of green products in the Egyptian market, a few others expressed relief because, recently, they have had access to responsible goods through online eco-shops.

"Whenever I get the chance, I buy green products. I love the idea that we can have access to such products through Instagram."-FA, Female, 25 years old.

As for using eco-labeled goods, most interviewees showed an almost absent knowledge towards them. They suggested that they might have bought eco-labeled products abroad, probably without knowing. Nevertheless, they all agreed to the total absence of eco-labeled products from the Egyptian market. On the other hand, the minority that purchased eco-labeled products from abroad had more details on green products and showed more awareness.

"All of the green products that I use are from abroad except my toothbrushes and stainless straws"-SA, Female, 25 years old.

Comparatively, the expert perspectives stated that people consume green products without knowing. For example, the frog (Rainforest Alliance label) on Costa Coffee's cup is noticeable, yet people do not recognize it or know its indication. Thus, experts believe that consumers need awareness of sustainability logos and stamps, and if they learn about their 
essence and contribution to the ecosystem, they would be encouraged and driven to make responsible purchases.

Moving to the next level of green product awareness, respondents were asked about their understanding of eco-labels. The findings reveal negligible knowledge or awareness of the young generation about eco-labeled products and sustainability stamps. They expressed that they are not familiar with the concept, or the ways certification bodies work. Moreover, when pointed out, the young participants failed to recognize the Rainforest Alliance logo on the Costa cup, even though they are all customers of Costa Coffee and are well acquainted with the brand. However, a few respondents explained that they noticed sustainability stamps while traveling abroad on some products, namely, the "Starbucks Fairtrade brownie"; however, they did not understand what it meant. They only associated it with "doing well" and "fairness," which made them feel good when buying the product. It is also important to point out that most of the participants, eventually, inquired about eco-labels and their means of operation, as well as their relationship with the environment and social responsibility. Notably, the young participants showed high engagement and eagerness to learn about and understand sustainability stamps, regardless of a few skeptical interviewees who were confused about whether to trust this process or not.

\subsection{Motivation}

In this section, the research's findings reveal the factors which motivate young consumers to become more sustainable and conscious. It also explores their values, beliefs, and feelings in association with positive behavioral patterns as well as good corporate citizenship. Additionally, it comprehends the magnitude of social influence's impact on the young generation's purchase decisions.

Participants explained that the more they learn about sustainability, the more they get involved and become concerned about becoming better inhabitants of the ecosystem. Accordingly, they explained that they would appreciate a platform that educates them about being more sustainable, adopting more responsible habits, understanding their footprint and their impact on the environment, and introducing them to sustainable products and tools which they can use to make their life easier and more convenient.

"I would like to learn about rational ways to be more sustainable, about green products and their availability, behavioral impacts, ecological challenges and their effects on our lives"-MH, Female, 22 years old.

Nonetheless, other respondents showed interest in learning more about corporate behavior, compliance processes, values, and practices. They claimed that consumers and corporates can motivate each other if they communicate transparently and work together towards a better environment. However, on the negative side, opponents disagreed with the idea that corporates would go out of their way to become more responsible, unless they are controlled by regulations and authorities.

Another compelling opinion of the respondents clarified that standardization and transparency are the factors that would make them trust corporates.

"There is nothing wrong with communicating downfalls, it makes us believe in the company even more because there is no such thing being the perfectly behaving company!"FS, Female, 23 years old.

Similarly, participants expressed their willingness to trust an eco-label if it communicates corporates' journey to becoming more sustainable and eco-friendlier. Surprisingly, the young generation is mindful of the sustainable transformation, that it is a process, and that it takes time and effort to generate achievements. Responses regarding responsible corporate citizenship were positive and appreciative.

"I 100\% feel good about companies who put effort into sustainability, at least they care!"-SA, Female, 25 years old. 
Egyptian corporates, as well as multinationals operating in Egypt, show great potential in establishing good relationships with their consumers as well as initiating new market opportunities to fill the gap in the green product market.

Values and beliefs are the strongest drives pushing a person to take a specific action in their life. As communicated in the literature, when triggered, emotions cause consumers to act or react. In other words, regarding environmental awareness, when paired with emotional concern, consumers tend to make conscious buying decisions to mitigate environmental challenges or simply feel better about themselves. The research participants explained that green product purchases induce self-appreciation and value. Ethical behavior motivates the young generation to take more responsible actions to do better themselves before positively affecting the ecosystem. Moreover, it is believed that with the right awareness and collective effort, individuals who adopt a more conscious lifestyle would have a positive impact on ecological restoration.

"Sustainable behavior and way of living would make a difference, for example, the way the planet recovered in the global quarantine because of the COVID19 pandemic proved how impactful our lifestyles are!"-OH, Male, 26 years old.

Another key point to motivation is the products available in the market and their corresponding prices. Participants stated that green product scarcity in the Egyptian market is holding them back from adopting a more responsible behavior. However, if available and of a good quality, the youngsters would immediately expand their product portfolio to include green products. Moreover, most of the respondents expressed that they understand the complexity of producing green products, in addition to the limited demand, which makes them more expensive than conventional products available in the market. Nonetheless, they revealed that companies should adopt innovative solutions and use their marketing creativity to increase the market demand for this type of product and reduce the corresponding costs. From their perspective, and in harmony with the global GenZers discussed in the literature [36], producers should target prices that match the normal product market prices.

"They should be around the same ranges of normal products. I understand they are more expensive because of the complex operation. However, they should make them closer to average prices." $-R D$, female, 26 years old.

Lastly, social influence proved efficient in spreading motivation across the young generation and helped them move towards responsible consumption patterns. Most of the participants mentioned that product recommendations from their trusted circles or online reviews about specific products would encourage them to try these goods and evaluate them themselves. This affirms the influential forms this generation endures as well as the importance of communication as a marketing tool to reach out to them.

\subsection{Action}

The results of the research show that when it comes to applications and changes in patterns and behaviors, most of the interviewees are enthusiastic and exhibit promising intentions to change their patterns and behaviors. All our respondents have changed at least one to a few habits towards sustainability and operate from an aware and conscious mindset: they are also looking to continue expanding the scope of sustainable living in their lives and apply it in many other aspects. However, the consistent concern and main factor that holds them back from applying this is the lack of availability of sustainable products and practices, and the difficulty and inconveniences they would have to endure to fully commit to a sustainable lifestyle in Egypt. When asked about her sustainable practices, MH, 21 said:

"I have initiated many practices in my life, however, I couldn't sustain any of them. For example, I use stainless-steel water bottles, yet I do not know where to refill them! We don't have a motivating infrastructure in Egypt to encourage sustainable living." 
Exhibiting a typical global Gen $\mathrm{Z}$ behavior, this sample shows a clear priority for convenience. Even though they are aware, most respondents show resistance to going out of their way to sustain these changes and the environment, where they can spare extra expenses within reason and budget, but more than half would not compromise quality, especially when it comes to health-related products, because, as health enthusiasts, they are aware of the implication of such a move and are not willing to risk the consequences. Dr. Beshara commented on this, explaining:

\section{"People think about their benefit more than the total wellness of the environment."}

Accordingly, it is important to reveal that convenience is one of the key factors not only affecting the young generation's purchase decision but also their lifestyle and identity. The literature explained the value of convenience as per Gen Z citizens globally; despite having ecological awareness and environmental concern, they still favor convenience and practicality in their daily lives [85]. From the same perspective, one of the experts who owns a green product business in Egypt shared her experience. She stated that through her interactions with customers, they prefer convenience over everything. Be it in the packaging, delivery, or handiness of the products, convenience is the key component of the purchasing experience.

As a result, branding has shown to be a major factor affecting their purchasing decision, especially if accredited by a source trusted to them or tried before by a friend or a family member. The brand would also be negatively impacted if associated with unethical or unsustainable practices, with the condition of the presence of an available and convenient substitute. One of the respondents shared her experience with "Lush" - one of the popular British cosmetics brands that possesses a global presence. The participant explained:

"Lush offer(s) good quality products that are convenient and safe, but what is amazing about that brand is their packaging concept. They have gone above and beyond with creativity and introduced the concept of naked-products where you can buy your soap in small paper bags, no boxes, no plastic wrap, just a paper bag."

Similarly, most respondents agreed that sustainable packaging is an attractive element during their shopping experience. Aside from being unique and creative, it also makes them feel ethical about their purchases and, eventually, consumerism, similar to global GenZers [24]. Thus, corporates can benefit from this insight and start developing new concepts and ideas for sustainable and environmental packaging. They can also benefit from limited customer expectations since they barely find such products in the Egyptian market.

The most popular practices sited during the interviews were plastic and water related, matching the results of awareness, replacing plastic utensils and resources with durable ones, moving from plastic bottles to reusable eco-friendly bottles, using a personal backpack and tote bags in supermarkets, switching to bamboo toothbrushes if and when available, consciously looking for sustainable packaging, and eco-friendly methods of waste disposal. Many interviewees have been donating unwanted food to stray animals and clothes to NGOs while recycling disposable materials at home.

"I reduced junk food because the corresponding industries have completely unsustainable supply chains with tons of waste because of their mass production."-BS, male, 29 years old.

Additionally, on the water preservation front, the participants show active concern for water scarcity and are reducing their water consumption daily. There were other changes in behavior mentioned such as printing on both sides of paper, recycling paper, and using bikes for transportation whenever possible.

"Our driver followed our lead; he asked about the reasons we behaved like that and after we explained that we're trying to reduce our harmful print on the environment, he started to change his behavior too."-OH, male, 26 years old.

Normally, trends are set by celebrities, designer houses, public figures, etc. Eventually, customers aspire to a trendy life and follow their leads. In particular, one young participant 
explained that their driver, who aspired to their life and looked up to his employers, was curious to understand sustainable behavior which did not seem familiar. As a result, aspiration and awareness inspired the driver to change his behavior and adopt a new habit induced by responsibility. By the same token, marketing plays a big role in communicating with the targeted customers. An expert participant explained that there is a different strategy for every population segment. In other words, the method of communication differs from one socioeconomic class to another. The expert added that the way to approach the population's top tier is through branding, trendsetting, and creativity. However, aspiration would be the trigger to the middle class, followed by cost reduction ideas to communicate with any population's $C$ class. Consequently, if the right communication strategy is utilized, awareness can be raised, and thus consumerism can be optimized.

The sustainability experts who acted as participants put a lot of weight on the importance of corporate responsibility to benefit from the exciting circle of green consumers, use them as a base, and build stronger and bigger platforms, expanding from an exciting unfulfilled potential point.

They continued by stating that building communication and reaching them through their emotional ports is the way to grab their attention and influence their purchasing action. Serving them with the convenience that they expect and through their needs would promote a beneficial flow of their products off shelves. More importantly, focusing on Generation Z, a sense of community is highly recommended. Experts believe that if companies build on the existing communities and expand them, they will influence more community members and attract them to join the responsible consumerism movement.

\subsection{Advocacy}

When we discuss people's behavior regarding sustainability, it is quite interesting to study their advocates' perspective and not only the aware segment. Every individual could make a massive difference, impacting positive behavior when advocacy takes place, as word of mouth constitutes a key factor shaping consumers' perspectives and attitudes. Some interviewees stated that they are in a transitional phase, meaning that they are becoming more responsible for shedding light on sustainability. Some others expressed their aspiration for representing sustainable living and encouraging their communities to tag along. Ultimately, there are trigger points within the Egyptian environment that either boost environmental advocacy or bring it down.

The young GenZers showed enthusiasm for ecological lifestyle transformations. They agreed that there would not be any way around moving towards conscious life patterns and behaviors. However, they pointed out challenges that face any Egyptian sustainability enthusiast.

"I try, but it is not that easy or convenient to sustain a sustainable lifestyle in Egypt"OK, Male, 27 years old.

Notably, the difficulties lie in the small details of Egyptians' day-to-day lives. As an example, people tend to buy plastic water bottles throughout their day because there is no availability of good-quality filtered water to refill their sustainable bottles instead. Additionally, participants mentioned that even though they segregate their waste to prepare it for recycling, there are inconsistent and non-reliable companies providing the service of waste collection. In this case, as mentioned by the participants, we lose hope and go back to conventional methods of dumping waste in landfills. As a result, some respondents preferred to make a slow switch to more sustainable behavior, where they can acquire new conscious habits based on their convenience and applicability.

"I am getting there. I am being smart about buying things, I am not an advocate though."-MH, Male, 22 years old.

In this context, respondents highlighted the fact that advocacy comes from friends more than family, which means Generation Z and even Generation Alpha. 
"My son is very aware because of his school. They educate them heavily about sustainability and he always checks whether we match the school behavioral pattern at home or not."-RK, Female, 29 years old.

This fact not only proves the importance of education in shaping the generation's mindset and behavior but also highlights the influence of young children on their parents. Another perspective entails that family, and especially older members, represent most of the Egyptian population, from the upper bracket age of Millennials and older. With some exceptions, Generation X represents a big hurdle in the way of the young generation's sustainability transformation. Furthermore, advocacy is tightly linked to the context or situation; some people do not bring up the topic of the environment unless someone asks, or they bring it up to avoid sarcasm, bullying, or emotional pressure. Moreover, most of the interviewees were skeptical about promoting green products voluntarily. Therefore, the purchase of green products is yet to be considered common practice.

"I am a bit skeptical to volunteer and talk about that because I feel people are unaware and not interested"-MH, Female, 21 years old.

It is claimed that the society in Egypt does not encourage sustainability to the extent of creating a strong platform for it. Accordingly, big companies that are credible enough to raise awareness about the environment are not embracing this strategy as they are more profit oriented.

"I don't think companies will do well unless they receive incentives. They are capitalists and they care more about their profitability"-BS, Male, 29 years old.

Considering this point of view, it is possible to identify some lack of trust in businesses within a specific segment of the young generation. In addition to this, the interview findings show the existence of a significant gap in communicating business values to customers. The youngsters communicated that they usually are not aware of different brands' values unless there is a specific scandal that caught the community's attention. However, some respondents indicated that in the case they learn that a brand's behavior does not match their values, they would immediately stop buying their products.

"Normally, I'm not aware of the company's behaviors and values. But if I knew, I would act accordingly. For example: if I find out that the company dumps its waste in the Nile River then it is a big NO for me."-RD, Female, 26 years old.

Thus, some segments are ready to boycott brands and products due to their unmatching values; they would look for more compliant alternatives. These insights indicate the potential of the green product market as well as the appreciation of the young generation of ethically behaving companies and sustainable brands. They also represent a category of consumers who are willing to go beyond being sustainable and reject harmful companies and their products.

In contrast, some interviewees were highly considerate of the values of companies, although they did not have sufficient information about them. They mentioned the necessity of the product versus the values of the company.

"(It) depends on the product. For example, the fashion industry is a mess and harmful, yet we do not stop shopping for clothes."-FA, Female, 25 years old.

This shows that the consumers select the necessity of, and their preference for, the product over its contribution to the environment. Likewise, the Indian Generation $\mathrm{Z}$ tends to understand the impact of unsustainable products on the environment and prefers buying eco-friendly products; however, the lack of availability of green products and their corresponding high prices do not give them the luxury of choosing [50].

Finally, it was noticed that the Egyptian Gen $Z$ advocates lean towards healthier lifestyles when it comes to food choices. More specifically, two of the participants mentioned that they are vegans because it is better for their health as well as for the environment and animal welfare. Despite being a minority, the vegan community in Egypt is catching momentum and is slowly expanding. 


\section{Conclusions}

This study adopted a qualitative methodological approach to obtain data from the Egyptian Generation $Z$ through in-depth interviews to answer the research question: does the ecological awareness of the Egyptian Generation $Z$ reflect on their consumerism, echoing a change in the Egyptian market and corporate approach to customer retainment? Therefore, the objective of this study was to understand the level of sustainability consciousness of the young generation in Egypt, their consumerism, and their impression of green products. This study addressed the gap in the literature by providing a deep understanding of Generation $\mathrm{Z}$ and sustainable consumerism in a new context of the developing country of Egypt.

Thus, Egyptian GenZers were closely examined through qualitative research to reveal their orientation and perspective towards green products and sustainable consumption. The results were structured in a framework conveying four layers of sustainability behavior: Awareness, Motivation, Action, and Advocacy. As with the global GenZers, the Egyptian young population showed a remarkably significant level of awareness developed by their exposure to digital media platforms as well as their experiences with their own economic and ecological challenges $[63,92,93]$. However, this awareness was not directly translated to positive actions towards sustainable consumption because there were several challenges that dominated the responses of the study participants: lack of awareness, water scarcity, waste management, and poor education systems. Moreover, the empirical data revealed that there is a clear gap in communication between the authorities and citizens, considering the absence of the government's role in leading sustainability change through environmental regulations and action plan enforcement. This finding indicates the lack of governmental support to sustainable consumption in the developing countries context, which contradicts previous research that highlights the role of the government in developed countries such as the UK [94].

Furthermore, the Egyptian GenZers showed minimal awareness about green products, due to their minimal availability in the Egyptian market, besides being mostly accessible only through online e-commerce retailers. This lack of green product availability demotivates Egyptians to go green and change their consumption behavior towards sustainability. Thus, this finding supports prior research that argues that the country context and surrounding environment influence customers' choice to follow ethical consumption [75]. On the other hand, the young generation showed zero awareness about sustainable certifications and eco-labeled products because of their complete absence from the Egyptian market. However, participants expressed their enthusiasm for and appreciation of green initiatives and corporate sustainability. Despite the immaturity of young consumers regarding sustainable products, they showed a high interest and willingness to adopt more sustainable lifestyles and conscious buying if they have access to products and tools. When it comes to the sustainable consumerism action, they communicated that convenience is the key factor in any purchase decision, with a clear constraint of not compromising their health and wellbeing. Despite the fact the current literature shows that customers are willing to pay more for eco-friendly and sustainable products [6,77] Egyptian GenZers placed convenience as their main priority. This could be because Egypt is a low-income country, and the majority of the population cannot afford the cost of sustainable and green products as in high-income countries.

Despite the insignificance in the proportion of the population of Egypt, a segment of the young generation showed an in-depth understanding of sustainability challenges. This insight also highlights the potential future for local and small businesses. Some participants stated that they constantly look for local small businesses and aim to buy their products, not only because of the footprint reduction and economic vitality, but also because local businesses induce a healthy environment, reduce unemployment, and encourage sustainable ecosystems. All respondents confirmed that they have changed at least one of their habits to become more sustainable. This entails that the wave of change has already started for the young generation; however, it is moving at a slow pace due to 
the lack of available tools and products. Moreover, the government's role is absent, which does not provide a fertile environment for sustainable growth; on the contrary, it makes the change more challenging. Egyptian GenZers are at the early stages of the transition towards sustainable consumerism; however, there are trigger points within the Egyptian environment that either boost environmental advocacy or bring it down.

Finally, the future of Egyptian consumers will likely catch up with the global movement of sustainable development with eagerness to have access to green products and a clear welcoming attitude towards eco-labeling. In that sense, corporates would not have a choice but to transform their operations to become more responsible as well as introducing a new generation of local Egyptian green products. With the right marketing and communication, as well as governmental support, both the Egyptian consumers and the commercial sector would flourish in a sustainable environment. Without a doubt, this movement would lead the country towards a better future and more sustainable living.

\section{Practical Implications}

In recent years, the Egyptian government has been working on Egypt Vision 2030 [95] following the United Nations' Sustainable Development Goals framework, which was published in May 2016. However, it seems that there is a clear gap in the communication channel between the government and the citizens since none of the interviewees mentioned having any knowledge about it. A minority were aware of the logo of the Egypt Vision 2030 campaign; however, they did not recognize its core message. Consequently, the Egyptian government not only needs to enforce regulatory rules to bring its 2030 vision to life but also needs to work extensively on raising population awareness through integrating this vision in all aspects of life: for instance, education curriculums, private sector regulations for manufacturing and compliance, facilities, services, and amenities. The compliance with environmental and social standards should become visible and tangible so that people sense their essence and start living by them. Experts' opinions were supportive of the young generation's view of perceiving the government as the main driver behind rising consumer awareness. One of the participating experts in the study, owning a business selling green products online, explained that the government should convey to Egyptians that unsustainable practice is only going to harm their living and make their children suffer. Additionally, they should offer incentives to encourage green businesses and corporations to adopt responsible approaches through their operations and supply chains. Both citizens and businesses should be encouraged to move towards more sustainable living, and awareness is just the start.

Mass awareness and sensitization of consumers on eco-labeled products should be carried out. In so doing, consumers will be able to pick sustainability-labeled goods when shopping [45]. Consumer organizations, which include non-governmental organizations (NGOs), the government, and the food industry, should work together to sensitize consumers on certified products. The government should also ensure legislation of laws that govern fair trade to ensure sustainable development.

\section{Limitations and Future Research}

While this study is among the earliest to study the Egyptian Gen Z's consumerism and sustainability behaviors, it has some limitations. First, the research was based on qualitative methods as a means to profoundly understand the young Egyptian generation and collect insights indicating the ways they reflect and behave. However, the sample number and its corresponding pool of selection were limited to the extended surrounding community of the researchers, and thus it is not an adequate representation of the young generation. Additionally, the sampling of the esteemed participants was limited to a single geographic location, Greater Cairo, which disregards a significant portion of the generation belonging to the same selected socioeconomic class living in other cities such as Alexandria, Delta, and Assiut. 
Therefore, it is recommended that future studies use quantitative methods with representative sample numbers, where the content proposed by this study could be validated. Furthermore, researchers may aim to widen the pool of selection to include more geographical locations, educational backgrounds, different school systems, and various psychographics. Finally, it might be interesting to examine the young school students of Generation Z to study their awareness level and commitment to the environment. Accordingly, the results might reflect the impact of educational entities on raising sustainability consciousness and eventually draw an indication about the future Egyptian citizens, consumers, and leaders.

Author Contributions: Conceptualization, S.K. and A.I.; conceiving the research idea and performing the theoretical study, S.K.; methodology, S.K. and S.G.; collecting data, S.K.; data analysis, S.K. and S.G.; writing the paper, S.K.; supervising the whole project, A.I.; arranging references and citations, editing, and reviewing the manuscript, S.G. All authors have read and agreed to the published version of the manuscript.

Funding: This research received no external funding.

Institutional Review Board Statement: The research methodology has been approved by the American University in Cairo's Institutional Review Board (IRB). The IRB committee guarantees the research was handled ethically and with full protection of the participants' rights and privacy, following FDA regulations.

Informed Consent Statement: Informed consent was obtained from all subjects involved in the study.

Data Availability Statement: Not applicable.

Conflicts of Interest: The authors declare no conflict of interest.

\section{References}

1. Ascensão, F.; Fahrig, L.; Clevenger, A.P.; Corlett, R.T.; Jaeger, J.A.; Laurance, W.F.; Pereira, H.M. Environmental challenges for the Belt and Road Initiative. Nat. Sustain. 2018, 1, 206-209. [CrossRef]

2. Woodruff, A.; Mankoff, J. Environmental sustainability. IEEE Pervasive Comput. 2008, 8, 18-21. [CrossRef]

3. Imeson, A. Desertification, Land Degradation and Sustainability; Wiley: Chichester, UK, 2012.

4. Turner, A. Generation Z: Technology and Social Interest. J. Individ. Psychol. 2015, 71, 103-113. [CrossRef]

5. Dabija, D.C.; Bejan, B.M.; Dinu, V. How sustainability oriented is Generation Z in retail? A literature reviews. Transform. Bus. Econ. 2019, 18, 140-155.

6. Su, C.H.J.; Tsai, C.H.K.; Chen, M.H.; Lv, W.Q. US sustainable food market generation Z consumer segments. Sustainability 2019, 11, 3607. [CrossRef]

7. Dolot, A. The characteristics of Generation Z. E-Mentor 2018, 2, 44-50. [CrossRef]

8. Mensah, J. Sustainable development: Meaning, history, principles, pillars, and implications for human action: Literature review. Cogent Soc. Sci. 2019, 5, 1653531. [CrossRef]

9. Gruner, R.L.; Power, D. Mimicking natural ecosystems to develop sustainable supply chains: A theory of socio-ecological intergradation. J. Clean. Prod. 2017, 149, 251-264. [CrossRef]

10. Hobson, K. Environmental psychology and the geographies of ethical and sustainable consumption: Aligning, triangulating, challenging? Area 2006, 38, 292-300. [CrossRef]

11. The Nielsen Company. The Sustainability Imperative: New Insights on Consumer Expectations. 2015. Available online: https://www.nielsen.com/content/dam/nielsenglobal/dk/docs/global-sustainability-report-oct-2015.pdf (accessed on 1 September 2021).

12. Biswas, A.; Roy, M. Green products: An exploratory study on the consumer behaviour in emerging economies of the East. $J$. Clean. Prod. 2015, 87, 463-468. [CrossRef]

13. Rana, J.; Paul, J. Consumer behavior and purchase intention for organic food: A review and research agenda. J. Retail. Consum. Serv. 2017, 38, 157-165. [CrossRef]

14. Jad'ud'ová, J.; Badida, M.; Badidová, A.; Marková, I.; Ťahúňová, M.; Hroncová, E. Consumer behavior towards regional eco-labels in Slovakia. Sustainability 2020, 12, 5146. [CrossRef]

15. Mihajlović, B. The Role of Consumers in the Achievement of Corporate Sustainability through the Reduction of Unfair Commercial Practices. Sustainability 2020, 12, 1009. [CrossRef]

16. Van Doorn, J.; Verhoef, P.C.; Risselada, H. Sustainability Claims and Perceived Product Quality: The Moderating Role of Brand CSR. Sustainability 2020, 12, 3711. [CrossRef]

17. Yoon, Y.; Gurhan-Canli, Z.; Schwarz, N. The Effect of Corporate Social Responsibility (CSR) Activities on Companies with Bad Reputations. J. Consum. Psychol. 2006, 16, 377-390. [CrossRef] 
18. Tobler, C.; Visschers, V.; Siegrist, M. Eating green. Consumers' willingness to adopt ecological food consumption behaviors. Appetite 2011, 57, 674-682. [CrossRef]

19. Barber, N.A.; Bishop, M.; Gruen, T. Who pays more (or less) for pro-environmental consumer goods? Using the auction method to assess actual willingness-to-pay. J. Environ. Psychol. 2014, 40, 218-227. [CrossRef]

20. Maichum, K.; Parichatnon, S.; Peng, K.C. Factors affecting on purchase intention towards green products: A case study of young consumers in Thailand. Young 2017, 16, 17.

21. Horne, R.E. Limits to labels: The role of eco-labels in the assessment of product sustainability and routes to sustainable consumption. Int. J. Consum. Stud. 2009, 33, 175-182. [CrossRef]

22. Lumpur, U.K.; Hulu, J. Overview of 'Generation Z' Behavioral Characteristic and Its Effect towards Hostel Facility. Int. J. Real Estates Stud. 2017, 11, 59-67.

23. Schaefer, A.; Crane, A. Addressing Sustainability and Consumption. J. Macromark. 2005, 25, 76-92. [CrossRef]

24. Merriman, M. What if the Next Big Disruptor Isn't a What But a Who? Ernest Young LLp. 2015. Available online: https://www.yumpu.com/en/document/read/54544003/what-if-the-next-big-disruptor-isnt-a-what-but-a-who (accessed on 1 September 2021).

25. Topic, M.; Mitchell, B. Generation Z E Consumer Trends in Environmental Packaging; Retail Institude: Leeds, UK, $2019 ;$ pp. 1-21.

26. Francis, T.; Hoefel, F. "True Gen": Generation Z and Its Implications for Companies; McKinsey \& Company: 2018. Available online: https:/ / www.mckinsey.com/industries/consumer-packaged-goods/ourinsights/true-gen-generation-z-and-itsimplications-for-companies (accessed on 1 September 2021).

27. Chowdhury, R.; Moore, G.A.; Weatherley, A.J.; Arora, M. Key sustainability challenges for the global phosphorus resource, their implications for global food security, and options for mitigation. J. Clean. Prod. 2017, 140, 945-963. [CrossRef]

28. Britain Thinks. Future Consumer: Food and Generation Z. 2019. Available online: https://www.food.gov.uk/sites/default/files/ media/document/generation-z-full-report-final.pdf (accessed on 1 September 2021).

29. Singh, A.P.; Dangmei, J. Understanding the generation Z: The future workforce. South-Asian J. Multidiscip. Stud. $2016,3,1-5$.

30. Özkan, P.M. Generation Z-the global market's new consumers-and their consumption habits: Generation Z consumption scale. Eur. J. Multidiscip. Stud. 2017, 2, 150-157. [CrossRef]

31. Broadbent, E.; Gougoulis, J.; Lui, N.; Pota, V.; Simons, J. Generation Z: Global Citizenship Survey. What the World's Young People Think and Feel, Varkey Foundation. 2017, pp. 26-44. Available online: http:/ / knowledge4all.com/Temp/Files / f905c620-6d2b4938-96cd-9f5d8373815c.pdf (accessed on 20 October 2021).

32. Natural Marketing Institute. Understanding the LOHAS Market Report. 2008. Available online: www.NMIsolutions.com (accessed on 17 June 2020).

33. OC\&C Strategy Consultants. A Generation without Borders-Embracing Generation Z. 2019. Available online: https://www. occstrategy.com/media/1806/a-generation-without-borders.pdf (accessed on 12 October 2021).

34. Noor, M.N.M.; Jumain, R.S.A.; Yusof, A.; Ahmat, M.A.H.; Kamaruzaman, I.F. Determinants of generation Z green purchase decision: A SEM-PLS approach. Int. J. Adv. Appl. Sci. 2017, 4, 143-147. [CrossRef]

35. Parry, E.; Battista, V. Generation Z in the UK: More of the Same-High Standards and Demands. Gener. Z Eur. 2019, 89-107. [CrossRef]

36. Rothman, D. A Tsunami of Learners Called Generation Z. 2016. Available online: http://www.mdle.net/JoumaFA_Tsunami_of_ Learners_Called_Generation_Z.pdf (accessed on 1 September 2021).

37. Madjid, A.; Bahiroh, S. cultivating soft life skills for generation $\mathrm{z}$ toward opportunities and challenges in the era of fourth industrial revolution. J. Crit. Rev. 2020, 7, 2190-2196.

38. GlobeScan. The State of Sustainable Business 2018: Results of the 10th Annual Survey of Sustainable Business Leaders. Bus. Soc. Responsib. 2018. Available online: https:/ / www.bsr.org/en/our-insights/report-view/state-of-sustainable-business-2018-bsrglobescan (accessed on 20 June 2019).

39. Kamenidou, I.C.; Mamalis, S.A.; Pavlidis, S.; Bara, E.Z.G. Segmenting the generation Z cohort university students based on sustainable food consumption behavior: A preliminary study. Sustainability 2019, 11, 837. [CrossRef]

40. Dunas, D.V.; Vartanov, S.A. Emerging digital media culture in Russia: Modeling the media consumption of generation Z. J. Multicult. Discourses 2020, 15, 186-203. [CrossRef]

41. Jackson, T. Sustainable consumption. In Handbook of Sustainable Development; Edward Elgar Publishing: Cheltenham, UK, 2007; pp. 254-268.

42. Cohen, M.; Murphy, J. Exploring Sustainable Consumption: Environmental Policy and the Social Sciences; New Jersey Institute of Technology: Newark, NJ, USA, 2001.

43. Jackson, T.; Michaelis, L. Policies for Sustainable Consumption; Sustainable Development Commission: London, UK, 2003.

44. Akenji, L. Consumer scapegoatism and limits to green consumerism. J. Clean. Prod. 2014, 63, 13-23. [CrossRef]

45. Zaharia, I.; Zaharia, C. The growth of environmentally sustainable consumerism. Econ. Manag. Financ. Mark. $2015,10,115$.

46. Smith, T.E.; Winton, M.; Yoshioka, M. A qualitative understanding of reflective-teams II: Therapists' perspectives. Contemp. Fam. Ther. 1992, 14, 419-432. [CrossRef]

47. Ferreira, A.I.; Ribeiro, I. Are you willing to pay the price? The impact of corporate social (ir)responsibility on consumer behavior towards national and foreign brands. J. Consum. Behav. 2016, 16, 63-71. [CrossRef] 
48. Black, I.R.; Cherrier, H. Anti-consumption as part of living a sustainable lifestyle: Daily practices, contextual motivations and subjective values. J. Consum. Behav. 2010, 9, 437-453. [CrossRef]

49. Cherrier, H.; Black, I.R.; Lee, M. Intentional non-consumption for sustainability: Consumer resistance and/or anti-consumption? Eur. J. Mark. 2011, 45, 1757-1767. [CrossRef]

50. Lee, M.S.; Ahn, C.S.Y. Anti-consumption, materialism, and consumer well-being. J. Consum. Aff. 2016, 50, 18-47. [CrossRef]

51. Lee, M.; Roux, D.; Cherrier, H.; Cova, B. Anti-consumption and consumer resistance: Concepts, concerns, conflicts and convergence. Eur. J. Mark. 2011, 45. [CrossRef]

52. Basci, E. A revisited concept of anti-consumption for marketing. Int. J. Bus. Soc. Sci. 2014, 5, 160-168.

53. Mannetti, L.; Pierro, A.; Livi, S. Recycling: Planned and self-expressive behaviour. J. Environ. Psychol. 2014, 24, 227-236. [CrossRef]

54. Claudelin, A.; Uusitalo, V.; Hintukainen, I.; Kuokkanen, A.; Tertsunen, P.; Leino, M.; Linnanen, L. Increasing positive climate impact by combining anti-consumption and consumption changes with impact investing. Sustain. Dev. 2020, 28, 1689-1701. [CrossRef]

55. Orzan, G.; Cruceru, A.F.; Bălăceanu, C.T.; Chivu, R.-G. Consumers' Behavior Concerning Sustainable Packaging: An Exploratory Study on Romanian Consumers. Sustainability 2018, 10, 1787. [CrossRef]

56. Fischer, D.; Böhme, T.; Geiger, S.M. Measuring young consumers' sustainable consumption behavior: Development and validation of the YCSCB scale. Young Consum. 2017, 18, 312-326. [CrossRef]

57. Markič, O. Rationality and emotions in decision making. Interdiscip. Descr. Complex Syst. INDECS 2009, 7, 54-64.

58. Jaiswal, D.; Singh, B. Toward sustainable consumption: Investigating the determinants of green buying behaviour of Indian consumers. Bus. Strat. Dev. 2018, 1, 64-73. [CrossRef]

59. Nawaz, W.; Koç, M. Exploring Organizational Sustainability: Themes, Functional Areas, and Best Practices. Sustainability 2019, 11, 4307. [CrossRef]

60. Seyrek, I.H.; Gul, M. Factors Affecting Green Purchasing Behavior: A Study of Turkish Consumers. Int. J. Acad. Res. Bus. Soc. Sci. 2017, 7, 306-319. [CrossRef]

61. Zhu, Q.; Sarkis, J. Green marketing and consumerism as social change in China: Analyzing the literature. Int. J. Prod. Econ. 2016, 181, 289-302. [CrossRef]

62. Sarkar, A. Green Branding and Eco-innovations for Evolving a Sustainable Green Marketing Strategy. Asia-Pac. J. Manag. Res. Innov. 2012, 8, 39-58. [CrossRef]

63. Kozinets, R.V.; Belz, F.M.; McDonagh, p. Social media for social change: A transformative consumer research perspective. In Transformative Consumer Research for Personal and Collective Well-Being; Routledge: New York, NY, USA, 2012; pp. $233-252$.

64. Laszlo, C.; Zhexembayeva, N. Embedded Sustainability: The Next Big Competitive Advantage; Routledge: New York, NY, USA, 2017.

65. Miles, M.P.; Munilla, L.S.; Darroch, J. Sustainable corporate entrepreneurship. Int. Entrep. Manag. J. 2008, 5, 65-76. [CrossRef]

66. Grunert, K.G.; Hieke, S.; Wills, J. Sustainability labels on food products: Consumer motivation, understanding and use. Food Policy 2014, 44, 177-189. [CrossRef]

67. Van Loo, E.J.; Caputo, V.; Nayga, R.M., Jr.; Seo, H.S.; Zhang, B.; Verbeke, W. Sustainability labels on coffee: Consumer preferences, willingness-to-pay and visual attention to attributes. Ecol. Econ. 2015, 118, 215-225. [CrossRef]

68. Annunziata, A.; Mariani, A.; Vecchio, R. Effectiveness of sustainability labels in guiding food choices: Analysis of visibility and understanding among young adults. Sustain. Prod. Consum. 2018, 17, 108-115. [CrossRef]

69. Janßen, D.; Langen, N. The bunch of sustainability labels-Do consumers differentiate? J. Clean. Prod. 2017, 143, 1233-1245. [CrossRef]

70. Abdu, N.; Mutuku, J. Willingness to pay for socially responsible products: A meta-Analysis of coffee ecolabelling. Heliyon 2021, 7, e07043. [CrossRef]

71. Balzarova, M.A. Blockchain technology-A new era of ecolabelling schemes? Corp. Gov. Int. J. Bus. Soc. 2020, $21,159-174$. [CrossRef]

72. Rainforest Alliance. Sustainable Agriculture Standard: Applicable for Smallholders Farms. 2018, pp. 1-41. Available online: https:/ / www.rainforest-alliance.org/business/wp-content/uploads/2019/02/rainforest-alliance-sustainable-agriculturestandard-smallholders-v1.0.pdf (accessed on 16 May 2020).

73. Bringing Your Story to Life: Marketing Examples from Partner Companies I Rainforest Alliance for Business. Available online: https: / / www.rainforest-alliance.org/business/marketing-sustainability/bringing-your-story-to-life-marketing-examplesfrom-partner-companies / (accessed on 16 May 2020).

74. Beekman, G.; Dekkers, M.; Koster, T. Towards a Sustainable Banana Supply Chain in Colombia: Rainforest Alliance Certification and Economic, Social and Environment Conditions on Small-Scale Banana Plantations in Magdalena, Colombia (No. 2019-019); Wageningen Economic Research: Wageningen, The Netherlands, 2019. [CrossRef]

75. Grauel, J. Being authentic or being responsible? Food consumption, morality and the presentation of self. J. Consum. Cult. 2014, 16, 852-869. [CrossRef]

76. Andersen, A.H. Organic food and the plural moralities of food provisioning. J. Rural. Stud. 2011, 27, 440-450. [CrossRef]

77. Lee, K. Opportunities for green marketing: Young consumers. Mark. Intell. Plan. 2008, 26, 573-586. [CrossRef]

78. Hinton, E. "Changing the World One Lazy-Assed Mouse Click at a Time": Exploring the Virtual Spaces of Virtualism in UK Third Sector Sustainable Consumption Advocacy; Environment, Politics and Development Working Paper Series, WP\# 16; Department of Geography, King's College: London, UK, 2009. 
79. Nagy, Á.; Kölcsey, A. Generation Alpha: Marketing or Science. Acta Technol. Dubnicae 2017, 7, 107-115. [CrossRef]

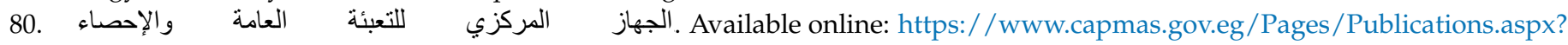
page_id=5104\&Year=23505 (accessed on 13 May 2020).

81. Pandit, V. We Are Generation Z: How Identity, Attitudes, and Perspectives Are Shaping Our Future; BrownBooks. ORM: Dallas, TX, USA, 2015.

82. Stebbins, R.A. Exploratory Research in the Social Sciences; Sage Publications: Thousand Oaks, CA, USA, $2001 ;$ p. 48.

83. Jansen, H. The Logic of Qualitative Survey Research and its Position in the Field of Social Research Methods. Forum Qual. Soz. Forum Qual. Soc. Res. 2017, 11. [CrossRef]

84. Creswell, J.W. Qualitative Inquiry and Research Design: Choosing among Five Approaches; SAGE Publications: Thousand Oaks, CA, USA, 2007.

85. Attride-Stirling, J. Thematic networks: An analytic tool for qualitative research. Qual. Res. 2001, 1, 385-405. [CrossRef]

86. Naderifar, M.; Goli, H.; Ghaljaei, F. Snowball Sampling: A Purposeful Method of Sampling in Qualitative Research. Strides Dev. Med. Educ. 2017, 14. [CrossRef]

87. Etikan, I.; Musa, S.A.; Alkassim, R.S. Comparison of Convenience Sampling and Purposive Sampling. Am. J. Theor. Appl. Stat. 2016, 5, 1-4. [CrossRef]

88. Biernacki, P.; Waldorf, D. Snowball Sampling: Problems and Techniques of Chain Referral Sampling. Sociol. Methods Res. 1981, 10, 141-163. [CrossRef]

89. Shenton, A.K. Strategies for ensuring trustworthiness in qualitative research projects. Educ. Inf. 2004, 22, 63-75. [CrossRef]

90. Olson, W. Triangulation in Social Research: Qualitative and Quantitative Methods Can Really Be Mixed. Dev. Sociol. 2004, 20, 103-118.

91. Holden, E.; Linnerud, K.; Banister, D. The Imperatives of Sustainable Development. Sustain. Dev. 2016, 25, 213-226. [CrossRef]

92. Pop, R.A.; Săplăcan, Z.; Alt, M.A. Social media goes green-The impact of social media on green cosmetics purchase motivation and intention. Information 2020, 11, 447. [CrossRef]

93. Strähle, J.; Gräff, C. The role of social media for a sustainable consumption. In Green Fashion Retail; Springer: Singapore, 2017; pp. 225-247.

94. Seyfang, G. Consuming values and contested cultures: A critical analysis of the UK strategy for sustainable consumption and production. Rev. Soc. Econ. 2004, 62, 323-338. [CrossRef]

95. Egypt Ministry of Planning, Monitoring and Administrative Reform. Sustainable Development Strategy: Egypt Vision 2030; Chapter: "Seventh Pillar: Education \& Training"; Egypt Ministry of Planning, Monitoring and Administrative Reform: Cairo, Egypt, 2016; pp. 6-8. 